\title{
ADSORBSI ION Cr(VI) MENGGUNAKAN ADSORBEN DARI LIMBAH PADAT LUMPUR AKTIF INDUSTRI CRUMB RUBBER
}

\section{Adsorption of $\mathrm{Cr}(\mathrm{VI})$ lon By Using Adsorbents from Activated Sludge Solid Waste of Crumb Rubber Industries}

\author{
Salmariza Sy ${ }^{1 \star}$, Mardiati $^{2}$, Mawardi $^{2}$, Sofyan $^{1}$, Ardinal $^{1}$, dan Yudo Purnomo ${ }^{1}$ \\ 1 Baristand Industri Padang, JIn. Raya LIK No. 23 Ulu Gadut Padang \\ 2 Fakultas MIPA Jurusan Kimia, Universitas Negeri Padang, JI. Prof. Dr. Hamka Air Tawar Padang \\ *e-mail: rizasalma@yahoo.co.id \\ Diterima: 6 September 2016, revisi akhir: 10 Desember 2016 dan disetujui untuk diterbitkan: 11 Desember 2016
}

\begin{abstract}
ABSTRAK
Penelitian tentang adsorbsi ion $\mathrm{Cr}(\mathrm{VI})$ dengan menggunakan adsorben dari limbah padat lumpur aktif industri crumb rubber telah dilakukan dengan metode statis (batch). Sampel yang digunakan adalah limbah padat lumpur aktif industri crumb rubber segar dan lumpur yang dikarbonisasi serta diaktivasi dengan $\mathrm{KOH}$. Parameter yang dipelajari yaitu $\mathrm{pH}$ awal larutan, waktu kontak, dan konsentrasi ion $\mathrm{Cr}(\mathrm{VI})$. Hasil penelitian menunjukan bahwa limbah padat lumpur aktif industri crumb rubber mengandung silika dan alumina yang tinggi yaitu $49,0 \%$ dan $16,5 \%$, sehingga dapat digunakan sebagai adsorben. $\mathrm{pH}$ optimum adsorben untuk lumpur diaktivasi yaitu pada $\mathrm{pH} 1$ dan lumpur segar pada $\mathrm{pH} 2$. Waktu kontak optimum yaitu 120 menit dan konsentrasi ion $\mathrm{Cr}(\mathrm{VI})$ optimum $70 \mathrm{mg} / \mathrm{L}$ untuk masingmasing adsorben. Data sesuai dengan isotherm Langmuir dengan kapasitas serapan maksimum terhadap ion $\mathrm{Cr}(\mathrm{VI}) 2,075 \mathrm{mg} / \mathrm{g}$ untuk adsorben lumpur diaktivasi dengan $\mathrm{KOH}$ dan 2,232 $\mathrm{mg} / \mathrm{g}$ untuk adsorben lumpur segar.
\end{abstract}

Kata Kunci: Adsorpsi, limbah lumpur aktif, industri crumb rubber, ion $\mathrm{Cr}(\mathrm{VI})$, isotherm Langmuir

\begin{abstract}
Research on ion $\mathrm{Cr}(\mathrm{VI})$ adsorption by using adsorbent from waste activated sludge crumb rubber industry has been done with static method (batch). The samples were fresh activated sludge solid waste of crumb rubber industry and carbonized sludge continued by $\mathrm{KOH}$ activated. Parameter were studied including solution $\mathrm{pH}$, contact time, and initial $\mathrm{Cr}(\mathrm{VI})$ ion concentration. The results reveal that the crumb rubber industrial waste activated sludge contained high silica and alumina, there were $49.02 \%$ and $16.498 \%$ respectively, so it can be used as an adsorbent. The adsorbent exhibited good adsorption potential at $\mathrm{pH} 1$ for the $\mathrm{KOH}$ activated sludge adsorbent and $\mathrm{pH} 2$ for the fresh sludge adsorbent, with 120 minutes optimum contact time and $70 \mathrm{mg} / \mathrm{L}$ initial concentration for each adsorbent type. Adsorption data were well described by the Langmuir isotherm with maximum adsorption capacities of $2.075 \mathrm{mg} / \mathrm{g}$ and $2.232 \mathrm{mg} / \mathrm{g}$ for $\mathrm{KOH}$ activated sludge adsorbent and fresh sludge adsorbent respectively.
\end{abstract}

Keywords : Adsorption, waste activated sludge, crumb rubber industry, Cr(VI),

\section{PENDAHULUAN}

Ion Chromium termasuk logam berat yang diklasifikasikan kedalam 16 besar substansi berbahaya oleh Agency for Toxic Substances and Disease Registry (ATSDR) (Jain, 2010). Perkembangan industri yang cepat selama bertahun-tahun menyebabkan peningkatan dan akumulasi $\mathrm{Cr}(\mathrm{VI})$ di lingkungan. Chromium berada di lingkungan dalam bentuk trivalen $[\mathrm{Cr}(\mathrm{III})]$ dan heksavalen $[\mathrm{Cr}(\mathrm{VI})]$ yang dianggap sangat beracun, karsinogenik, dan mutanogenik (Chen et al., 2011; Pillai et 
al., 2013). Ion $\mathrm{Cr}$ memberikan efek physiology bagi manusia dengan cara terakumulasi dalam rantai makanan dan menyebabkan berbagai penyakit seperti dapat menyebabkan kerusakan hati, ginjal, pendarahan di dalam tubuh, kerusakan saluran pernafasan dan kanker paru-paru (Venugopal \& Mohanty, 2011). Akibat efek yang sangat berbahaya dari chromium heksavalen menyebabkan pemerintah memasukkan chromium heksavalen dalam kriteria nilai baku mutu air. Menurut Peraturan Pemerintah Republik Indonesia nomor 82 tahun 2001, air hanya boleh mengandung chromium heksavalen maksimum 0.05 ppm. (Salmariza 2014). World Health Organization (WHO) juga menetapkan pedoman nilai chromium dalam air minum adalah 0,05 $\mathrm{mg} / \mathrm{L}$ (Javadian et al., 2013).

Sumber antropogenik chromium umumnya berasal berbagai proses industri seperti elektroplating, penyamakan kulit, pengawetan kayu, industri pewarna dan cat serta industri kertas. Bentuk kimia $\mathrm{Cr}(\mathrm{VI})$ sangat tergantung pada $\mathrm{pH}$ dan konsentrasi larutan. Biasanya ion $\mathrm{Cr}(\mathrm{VI})$ hadir dalam bentuk anionik, seperti $\mathrm{Cr}_{2} \mathrm{O}^{-2}{ }_{7}$ (dikromat), $\mathrm{HCrO}_{4}^{-}$(hidrogen kromat) atau $\mathrm{CrO}^{-2}{ }_{4}$ (kromat). Pada nilai $\mathrm{pH}$ di bawah 1 , $\mathrm{Cr}(\mathrm{VI})$ yang dominan adalah bentuk $\mathrm{H}_{2} \mathrm{CrO}_{4}$ (Asam kromik). Dalam media asam sekitar $\mathrm{pH} 2, \mathrm{Cr}(\mathrm{VI})$ sebagian besar berada dalam bentuk ion dikromat $\left(\mathrm{Cr}_{2} \mathrm{O}^{-2}\right)$. Pada $\mathrm{pH}$ antara 2 dan 6 , ion $\mathrm{Cr}_{2} \mathrm{O}^{-2}{ }_{7}$ dan $\mathrm{HCrO}_{4}^{-}$ berada dalam kesetimbangan, terutama dalam kondisi basa $(\mathrm{pH}>8) \mathrm{krom}$ hadir sebagai anion kromat (Javadian et al., 2013).

Beberapa proses pengolahan air limbah secara physikokimia telah dikembangkan dan dilaporkan untuk menghilangkan ion $\mathrm{Cr}(\mathrm{VI})$. Walaupun banyak metoda untuk mengolah air limbah yang mengandung logam berat, seperti presipitasi, pertukaran ion, dan membrane filtration, namun adsorpsi merupakan salah satu metoda yang dinilai ekomomis dan ecofriendly untuk menghilangkan $\mathrm{Cr}$ dari dalam air limbah. Seperti penelitian adsorpsi $\mathrm{Cr}$ menggunakan biomassa dari limbah pertanian corn stalks (Chen et al., 2011), potato starch (Pillai et al., 2013), tumbuhan gulma Parthenium hysterophorus (Venugopal et al., 2011), tumbuhan gulma Alligator (Wang et al. 2009), Biji Asam jawa (biji tamarind) dan Serbuk gergaji (Gupta \& Babu, 2009a dan 2009b), cornelian cherry dan kulit biji almond (Demirbas et al., 2004), daun casuarinas (Ranganathan, 2000). Begitu juga beberapa penelitian menggunakan adsorben dari limbah lumpur juga telah banyak dilakukan seperti penelitian pemanfaatan limbah lumpur sebagai penyerap logam $\mathrm{Cr}$ dalam larutan antara lain untuk ion $\mathrm{Cr}$ (III) (Liu et al., 2011; Iddou\&Quali, 2008), dan Cr(VI) (Wu et al., 2010; Gorzin et al., 2013), serta beberapa penelitian menggunakan lumpur dari sumber yang berbeda seperti diantaranya clarifield sludge dari industri baja (Bhattacharya, 2008), limbah lumpur pengolahan air limbah kota (Wu et al., 2010; Yang et al, 2010), limbah lumpur pabrik tekstil (Hunsom et al., 2013), pabrik kosmetik (Monsalvo et al 2012), pabrik sawit (Zaini et al., 2013), dan pabrik susu (Iddou \& Quali, 2008; Benaïssa \& Elouchdi, 2011).

Penelitian pemanfaatan limbah lumpur Instalasi Pengolahan air limbah (IPAL) industri crumb rubber sebagai bioadsorben belum banyak dilakukan. Penelitian yang telah dilaporkan yaitu untuk logam $\mathrm{Cr}$ dengan menggunakan aktivator $\mathrm{NaOH}$ dan $\mathrm{H}_{3} \mathrm{PO}_{4}$ (Salmariza, 2012; 2014). Lumpur yang diproses dengan karbonisasi dan aktivasi memiliki daya serap lebih baik dibandingkan dengan lumpur yang tidak dikarbonisasi dan diaktivasi (Salmariza, 2012).

Pada penelitian ini dipelajari kemampuan limbah lumpur industri crumb rubber PT Kilang Lima Gunung Lubuk Begalung Padang sebagai adsorben. Untuk meningkatkan daya serap dari lumpur, dilakukan proses karbonisasi dan aktivasi. Aktivator yang digunakan pada penelitian ini yaitu $\mathrm{KOH}$. Hwang et al., (2008) menerangkan mekanisme aktivasi dengan $\mathrm{KOH}$ dengan reaksi sebagai berikut:

$$
\begin{aligned}
& 2 \mathrm{KOH}(\mathrm{s}, \mathrm{l}) \rightarrow \mathrm{K}_{2} \mathrm{O}(\mathrm{s})+\mathrm{H}_{2} \mathrm{O}(\mathrm{g}) \\
& \mathrm{C}(\mathrm{s})+\mathrm{H}_{2} \mathrm{O}(\mathrm{g}) \rightarrow \mathrm{H}_{2}(\mathrm{~g})+\mathrm{CO}(\mathrm{g}) \\
& \mathrm{CO}(\mathrm{g})+\mathrm{H}_{2} \mathrm{O}(\mathrm{g}) \rightarrow \mathrm{H}_{2}(\mathrm{~g})+\mathrm{CO}_{2}(\mathrm{~g}) \\
& \mathrm{K}_{2} \mathrm{O}(\mathrm{s})+\mathrm{CO}_{2}(\mathrm{~g}) \rightarrow \mathrm{K}_{2} \mathrm{CO}_{3}(\mathrm{~s}, \mathrm{l}) \\
& \mathrm{K}_{2} \mathrm{O}(\mathrm{s})+\mathrm{H}_{2}(\mathrm{~g}) \rightarrow 2 \mathrm{~K}(\mathrm{l})+\mathrm{H}_{2} \mathrm{O}(\mathrm{g}) \\
& 2 \mathrm{~K}_{2} \mathrm{O}(\mathrm{s})+\mathrm{C}(\mathrm{s}) \rightarrow 4 \mathrm{~K}(\mathrm{l})+\mathrm{CO}_{2}(\mathrm{~g})
\end{aligned}
$$


Menurut Smith et al (2009) ada beberapa jenis senyawa kimia yang digunakan sebagai aktivator seperti $\mathrm{H}_{2} \mathrm{SO}_{4}, \quad \mathrm{H}_{3} \mathrm{PO}_{4}, \mathrm{KOH}, \mathrm{NaOH}, \quad \mathrm{ZnCl}_{2}$, $\mathrm{Fe}\left(\mathrm{NO}_{3}\right)_{3}$ and $\mathrm{K}_{2} \mathrm{CO}_{3}$, namun aktivator yang paling sering digunakan adalah $\mathrm{H}_{3} \mathrm{PO}_{4}$, $\mathrm{NaOH}, \mathrm{ZnCl}_{2}$, dan $\mathrm{KOH}$. Masing-masing jenis aktivator memberikan pengaruh yang berbeda terhadap luas permukaan yang dihasilkan. Selanjutnya dilakukan pengujian serapan adsorben terhadap ion logam $\mathrm{Cr}(\mathrm{VI})$. Agar proses adsorpsi terhadap logam $\mathrm{Cr}(\mathrm{VI})$ maksimal, maka perlu dilakukan pengujian kondisi optimum dari beberapa faktor yang mempengaruhi proses adsorpsi, diantaranya: pH, waktu kontak dan konsentrasi awal ion $\mathrm{Cr}(\mathrm{VI})$.

\section{METODOLOGI PENELITIAN}

Peralatan yang digunakan adalah peralatan gelas (pyrex), neraca analitik, muffle furnace Thermoline-6000, desikator, oven, ayakan test siever merek Retsch 5657 Haan W. Germany no. 60 dan 80 mess, shaker merek Adjustable Reciprocating Orbital Shaker (AROS)$160^{T M}$, magnetic stirrer, $\mathrm{pH}$ meter dan Spektrofotometer Serapan atom (SSA) merek AAS GBC 932 AA.

Bahan yang digunakan adalah limbah padat proses lumpur aktif dari sistem IPAL PT. Kilang Lima Gunung Lubuk Begalung Padang, $\mathrm{KOH}, \mathrm{HCl}$, $\mathrm{AgNO}_{3}, \mathrm{HNO}_{3}, \mathrm{NH}_{4} \mathrm{OH}, \mathrm{K}_{2} \mathrm{Cr}_{2} \mathrm{O}_{7}$, aquades, alumunium foil, dan kertas saring Whatman 42.

\section{Preparasi Sampel}

Limbah padat proses lumpur aktif diambil dari pabrik crumb rubber. Sampel dikeringkan dengan oven pada suhu $110^{\circ} \mathrm{C}$ selama 24 jam. Kemudian dihaluskan dan diayak menggunakan test siever no. 60 mess dan tertahan pada 80 mess dan siap digunakan sebagai adsorben segar. Sampel kemudian ditimbang sebanyak 200 gram dan dilakukan karbonisasi dalam Furnace pada suhu $600^{\circ} \mathrm{C}$ selama 1 jam sampai terbentuk arang. Sampel selanjutnya diaktivasi secara kimia dengan larutan $\mathrm{KOH} 2 \mathrm{~N}$ dengan perlakuan pengadukan dengan magnetic stirrer pada suhu $85^{\circ} \mathrm{C}$ selama 7 jam. Sampel lalu dibilas dengan larutan $\mathrm{HCl}$ 1,2 $\mathrm{M}$ dan aquades sampai $\mathrm{pH}$ netral dan bebas dari ion Cl. Untuk memastikan adsorben bebas dari ion $\mathrm{Cl}$, ditambahkan $\mathrm{AgNO}_{3} 1 \mathrm{M}$ pada filtrat sampai tidak terdapat endapan putih. Adsorben bebas klorida selanjutnya dikeringkan di dalam oven pada suhu $105^{\circ} \mathrm{C}$ selama 24 jam. Lalu didinginkan di dalam desikator selama 30 menit. Selanjutnya sampel siap digunakan sebagai adsorben.

\section{Analisis Kandungan Logam}

Penentuan serapan adsorben terhadap konsentrasi logam $\mathrm{Cr}(\mathrm{VI})$, dilakukan dengan menggunakan AAS, dengan bahan bakar udara-asetilen pada panjang gelombang $357,9 \mathrm{~nm}$ dan 428,9 $\mathrm{nm}$. Jumlah ion yang terserap oleh adsorben adalah selisih antara konsentrasi ion saat setimbang (dalam filtrat) dengan konsentrasi ion sebenarnya. Jumlah logam yang terserap dinyatakan sebagai berat (mg) logam yang terserap per berat (g) adsorben yang digunakan.

\section{Karakteristik Adsorben}

Karakterisasi adsorben dari limbah padat lumpur aktif industri crumb rubber dilakukan dengan menggunakan X-ray fluorescence spectrometer (XRF), Fourier Transform Infrared Spectrometer (FTIR) dan Scanning Electron Microscopy-Energy Dispersive X-ray Spectroscopy (SEM-EDX)

\section{Perlakuan dengan Sistem Batch Penentuan pH Optimum}

Adsorben ditimbang sebanyak 1 gram. Lalu ditambahkan $50 \mathrm{~mL}$ larutan ion logam dengan konsentrasi $10 \mathrm{mg} / \mathrm{L}$ dan $\mathrm{pH}$ $=1,2,3,4$ dan 5. Pengaturan $\mathrm{pH}$ dilakukan dengan menambahkan $\mathrm{NaOH}$ $0,01 \mathrm{M}$. Kemudian dishaker selama 30 menit dengan kecepatan putaran $180 \mathrm{rpm}$. Setelah itu disaring dan filtrat yang dihasilkan ditampung dan diukur dengan SSA.

\section{Penentuan Waktu Kontak Optimum}

Ditimbang adsorben sebanyak 1 gram. Lalu ditambahkan $50 \mathrm{~mL}$ larutan ion 
logam dengan konsentrasi $10 \mathrm{mg} / \mathrm{L}$ dan $\mathrm{pH}$ optimum. Kemudian dishaker dengan variasi waktu kontak yaitu: 30, 60, 120 dan 180 menit dengan kecepatan putaran 180 rpm. Setelah itu disaring dan filtrat yang dihasilkan ditampung dan diukur dengan SSA.

\section{Penentuan Konsentrasi Optimum Ion $\mathrm{Cr}(\mathrm{VI})$}

Ditimbang adsorben sebanyak 1 gram. Lalu ditambahkan $50 \mathrm{~mL}$ larutan ion logam $\mathrm{Cr}(\mathrm{VI})$ dengan konsentrasi 10, 20, 30, 40, 50, 60, 70, 80 dan 90 mg/L dengan $\mathrm{pH}$ optimum. Kemudian dishaker selama waktu kontak optimum yang diperoleh pada langkah dengan kecepatan putaran $180 \mathrm{rpm}$. Setelah itu disaring dan filtrat yang dihasilkan ditampung dan diukur dengan SSA.

\section{Teknik Analisis Data}

Konsentrasi masing-masing logam saat setimbang dan konsentrasi mula-mula ditentukan dengan AAS. Banyaknya ion $\mathrm{Cr}$ (VI) yang teradsorpsi (mg) per gram adsorben ditentukan dengan menggunakan persamaan 1:

$$
\mathrm{Qe}=\frac{V(\mathrm{Co}-\mathrm{Ce})}{m}
$$

Dimana Qe adalah jumlah zat yang teradsorpsi $(\mathrm{mg} / \mathrm{g})$, Co; konsentrasi $\mathrm{Cr}(\mathrm{VI})$ awal (mg/L), Ce; konsentrasi $\mathrm{Cr}(\mathrm{VI})$ akhir $(\mathrm{mg} / \mathrm{L}), \mathrm{m}$; berat adsorben (gram), V; volume larutan (L). Jumlah serapan maksimum adsorben ditentukan dengan persamaan isoterm adsorpsi Langmuir yang dapat dituliskan seperti persamaan 2:

$$
\frac{C}{a}=\frac{1}{a m K}+\frac{1}{a m} C
$$

Dimana C; konsentrasi kesetimbangan, a; jumlah zat yang teradsorpsi per gram adsorben $(\mathrm{mg} / \mathrm{g}), \mathrm{a}_{\mathrm{m}}$; kapasitas adsorpsi maksimum $(\mathrm{mg} / \mathrm{g})$, $\mathrm{K}$; tetapan kesetimbangan (afinitas serapan). Bila data yang diperoleh memenuhi persamaan tersebut di atas, maka plot C/a terhadap C akan menghasilkan garis lurus dengan slope $1 / a_{m}$ dan intersep $1 / a_{m} K$.

\section{HASIL DAN PEMBAHASAN Karakteristik Adsorben}

Hasil analisis karakterisasi adsorben dari limbah padat lumpur aktif industri crumb rubber yang dilakukan dengan menggunakan X-ray fluorescence spectrometer (XRF), Fourier Transform Infrared Spectrometer (FTIR) dan Scanning Electron Microscopy - Energy Dispersive $X$-ray Spectroscopy (SEMEDX) dapat dilihat pada Tabel 1, Gambar 1, dan Gambar 2.

Tabel 1. Komposisi adsorben dari limbah padat lumpur aktif tindusri crumb rubber dengan menggunakan XRF

\begin{tabular}{cccccc}
\hline $\begin{array}{c}\text { Unsur } \\
\text { Tunggal }\end{array}$ & Unit & $\begin{array}{c}\text { Dalam } \\
\text { bentuk } \\
\text { Senyawa } \\
\text { Geology }\end{array}$ & Unit & $\begin{array}{c}\text { Dalam } \\
\text { Bentuk } \\
\text { senyawa } \\
\text { Oxida }\end{array}$ & Unit \\
\hline $\mathrm{Al}$ & $13.5 \%$ & $\mathrm{~A}_{2} \mathrm{O}_{3}$ & $16.6 \%$ & $\mathrm{Al}_{2} \mathrm{O}_{3}$ & $16.5 \%$ \\
\hline $\mathrm{Si}$ & $38.9 \%$ & $\mathrm{SiO}_{2}$ & $49.3 \%$ & $\mathrm{SiO}_{2}$ & $49.0 \%$ \\
\hline $\mathrm{P}$ & $4.1 \%$ & $\mathrm{P}_{2} 0_{5}$ & $5.0 \%$ & $\mathrm{P}_{2} 0_{5}$ & $4.9 \%$ \\
\hline $\mathrm{S}$ & $3.4 \%$ & $\mathrm{SO}_{3}$ & $4.4 \%$ & $\mathrm{SO}_{3}$ & $4.4 \%$ \\
\hline $\mathrm{K}$ & $1.9 \%$ & $\mathrm{~K}_{2} \mathrm{O}$ & $1.2 \%$ & $\mathrm{~K}_{2} \mathrm{O}$ & $1.2 \%$ \\
\hline
\end{tabular}

Karakterisasi menggunakan metoda XRF pada Tabel 1 dapat dilihat bahwa adsorben dari limbah padat lumpur aktif industri crumb rubber mengandung silika dan alumina yang cukup tinggi yaitu berturut-turut $49.0 \%$ dan $16,5 \%$ yang 
diduga berperan sebagai sisi aktif adsorben dalam menyerap ion $\mathrm{Cr}(\mathrm{VI})$. Hal itu juga didukung oleh hasil karakterisasi menggunakan metoda photo SEM-EDX pada Gambar 1(A) yang memperlihatkan area permukaan adsorben yang tidak rata/berpori dimana akan menjadi area terjadinya impregnasi ion $\mathrm{Cr}(\mathrm{VI})$ serta Gambar 1(B) terlihatnya puncak spectrum unsur Al dan Si adsorben dari limbah padat lumpur aktif industri crumb rubber
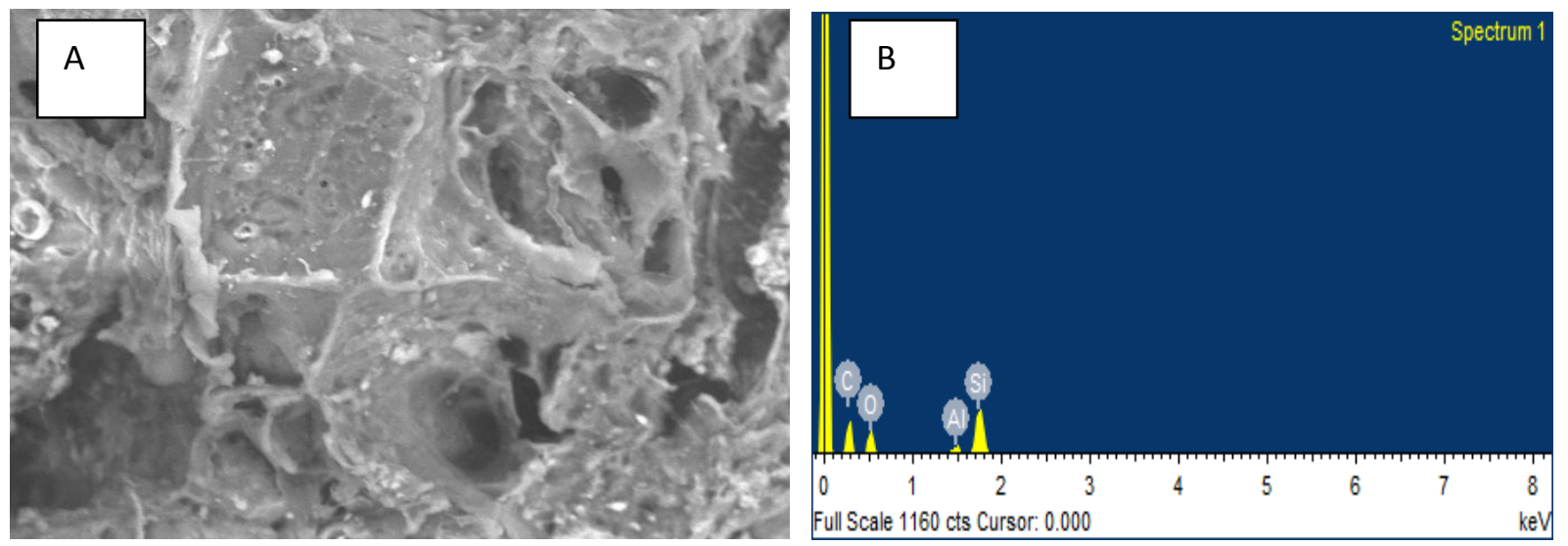

Gambar 1. Photo SEM (A) dan EDX (B) adsorben limbah padat lumpur aktif industri crumb rubber

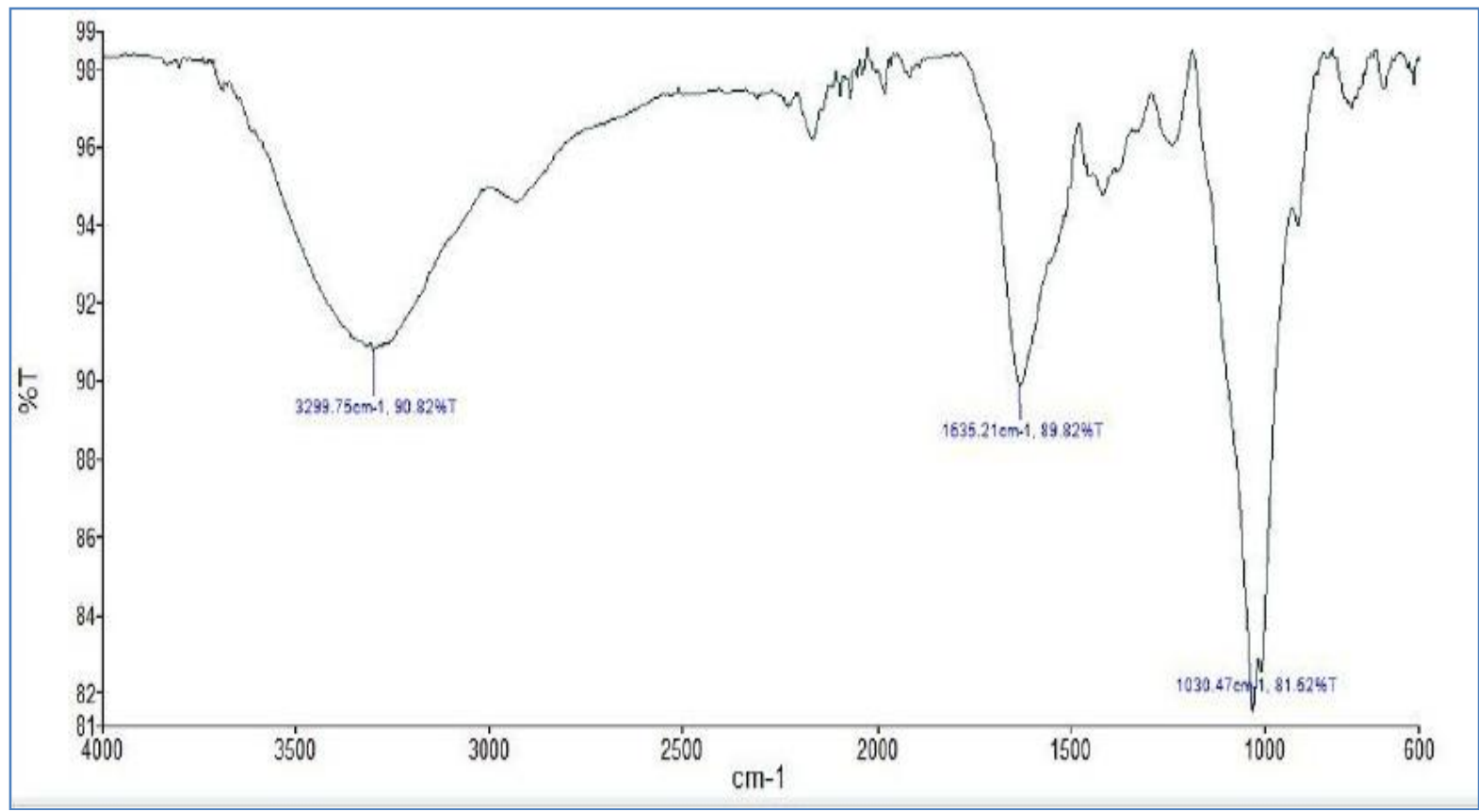

Gambar 2. Spektra FTIR adsorben limbah padat lumpur aktif industri crumb rubber

Karakterisasi menggunakan analisis spektrofotometri FTIR pada Gambar 2 dapat menunjukkan jenis gugus fungsi pada adsorben dari limbah padat lumpur aktif industri crumb rubber pada spektranya. Pola spektra adsorpsi dari adsorben yang dikembangkan dari limbah lumpur proses activated sludge industri crumb rubber menunjukkan pita lebar dengan puncak pada bilangan gelombang
$3299,75 \mathrm{~cm}^{-1}$ merupakan pita adsorpsi vibrasi gugus $\mathrm{O}-\mathrm{H}$. Adsorpsi pada 1030,47 $\mathrm{cm}^{-1}$ merupakan vibrasi ulur asimetri dari C- O (Zaini et al, 2013) dan vibrasi tekuk gugus $\mathrm{N}-\mathrm{H}$ ditunjukkan pada bilangan gelombang 1635,21 $\mathrm{cm}^{-1}$ (Siswoyo et al., 2014). Gugus fungsi-gugus fungsi tersebut sangat berperan dalam proses adsobsi ion $\mathrm{Cr}(\mathrm{VI})$ (Zaini et al., 2013 dan Siswoyo et al., 2014) 


\section{Pengaruh pH Awal Larutan}

Derajat keasamanan $(\mathrm{pH})$ merupakan faktor utama yang mempengaruhi adsorpsi logam dalam larutan karena akan berpengaruh pada muatan situs aktif adsorben dan spesies logam yang ada dalam larutan (Wiraman, 2011). Svehla (1985) menjelaskan bahwa ion $\mathrm{Cr}(\mathrm{VI})$ dalam larutan berupa anion kromat dan dikromat tergantung dari $\mathrm{pH}$ larutan.

$2 \mathrm{CrO}_{4}{ }^{2-}+2 \mathrm{H}^{+} \leftrightarrow \mathrm{Cr}_{2} \mathrm{O}_{7}{ }^{2-}+\mathrm{H}_{2} \mathrm{O}$ atau

$\mathrm{Cr}_{2} \mathrm{O}_{7}{ }^{2-}+2 \mathrm{OH}^{-} \leftrightarrow 2 \mathrm{CrO}_{4}{ }^{2-}+\mathrm{H}_{2} \mathrm{O}$

Reaksi ini juga ditulis sebagai:

$2 \mathrm{CrO}_{4}{ }^{2-}+2 \mathrm{H}^{+} \leftrightarrow 2 \mathrm{HCrO}_{4}^{-} \leftrightarrow \mathrm{Cr}_{2} \mathrm{O}_{7}{ }^{2-}+\mathrm{H}_{2} \mathrm{O}$

Pengaruh $\mathrm{pH}$ awal larutan terhadap adsorpsi $\mathrm{Cr}(\mathrm{VI})$ yang telah dilakukan dengan memvariasikan $\mathrm{pH}$ awal larutan yaitu 1, 2, 3, 4 dan 5 dengan konsentrasi masing-masing larutan adalah $10 \mathrm{mg} / \mathrm{L}$, didapatkan bahwa serapan $\mathrm{Cr}(\mathrm{VI})$ optimum oleh adsorben lumpur diaktivasi dengan $\mathrm{KOH}$ terjadi pada $\mathrm{pH} 1$ dengan serapan sebesar 0,291 $\mathrm{mg} / \mathrm{g}$ dan efisiensi penyerapan sebesar $78,28 \%$. Sedangkan untuk adsorben dari lumpur segar didapatkan serapan optimum $\mathrm{Cr}(\mathrm{VI})$ terjadi pada $\mathrm{pH} 2$ dengan serapan sebesar 0,22 $\mathrm{mg} / \mathrm{g}$ dan efisiensi penyerapan sebesar $77,13 \%$. Hal ini terjadi karena pada $\mathrm{pH}$ sangat asam permukaan adsorben dikelilingi oleh ion $\mathrm{H}^{+}$sehingga dapat menyerap adsorbat dalam keadaan anion kromat dan dikromat.

Bentuk dominan ion $\mathrm{Cr}(\mathrm{VI})$ pada $\mathrm{pH} 1$ adalah sebagai asam kromat ( $\mathrm{HCrO}^{-}$ (Wang et al., 2009) Selanjutnya Wang et al., (2009) melaporkan bahwa pH optimum untuk penyerapan ion $\mathrm{Cr}(\mathrm{VI})$ dengan alligator weed didapatkan pada $\mathrm{pH} 1$ dengan kapasitas adsorbsi maksimun $86,6 \%-99,7 \%$, sedangkan Jain et al., (2010) juga melaporkan bahwa penyerapan ion $\mathrm{Cr}(\mathrm{VI})$ dengan limbah padat biomassa di dapatkan pada $\mathrm{pH} 2$ dengan kapasitas adsorbsi maksimun 75,7\%-85,4\%.

Pengaruh $\mathrm{pH}$ terhadap jumlah ion $\mathrm{Cr}$ (VI) yang teradsorpsi disajikan dalam Gambar 3.

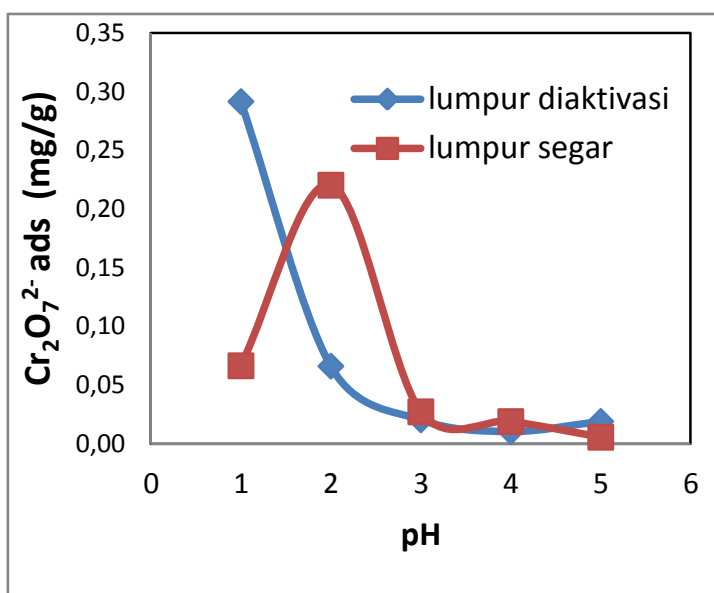

Gambar 3. Grafik pengaruh pH awal larutan ion $\mathrm{Cr}(\mathrm{VI})$ terhadap serapan adsorben (1 $\mathrm{g}$ adsorben, $50 \mathrm{~mL}$ larutan ion $\mathrm{Cr}(\mathrm{VI}) 10 \mathrm{mg} / \mathrm{L}$

\section{Penentuan Waktu Kontak Optimum}

Pengaruh waktu kontak antara adsorben dengan adsorbat dilakukan dengan melakukan variasi shaker yaitu 30; 60; 120; dan 180 menit pada $\mathrm{pH}$ optimum masing-masing adsorben yaitu berturut-turut pada $\mathrm{pH} 1$ dan $\mathrm{pH} 2$ untuk adsorben lumpur diaktivasi dan adsorben lumpur segar. Dari penelitian yang telah dilakukan terjadi peningkatan serapan dari 30 menit ke 120 menit dan terjadi penurunan serapan sejalan dengan peningkatan waktu kontak. Waktu kontak optimum untuk adsorben lumpur diaktivasi dengan adsorbat $\mathrm{Cr}(\mathrm{VI})$ yaitu pada 120 menit dengan serapan sebesar $0,393 \mathrm{mg} / \mathrm{g}$ dan efisiensi penyerapan sebesar $81,58 \%$. Sedangkan waktu kontak optimum adsorben lumpur segar dengan adsorbat $\mathrm{Cr}(\mathrm{VI})$ juga pada 120 menit dengan serapan sebesar $0,485 \mathrm{mg} / \mathrm{g}$ dan efisiensi penyerapan $99,81 \%$. Hal ini sesuai dengan Venugopal et al., (2011) yang menyatakan bahwa waktu kontak yang lebih lama memungkinkan proses difusi dan penempelan molekul adsorbat berlangsung lebih baik, namun pada kondisi dinama situs aktif sudah jenuh akan terjadi penurunan kapasitas penyerapan. Gambar 4 menunjukkan pengaruh waktu kontak terhadap adsorpsi ion $\mathrm{Cr}(\mathrm{VI})$ dalam setiap gram adsorben. 




Gambar 4. Grafik pengaruh waktu kontak terhadap serapan adsorben (1 $\mathrm{g}$ adsorben, $50 \mathrm{~mL}$ larutan ion $\mathrm{Cr}(\mathrm{VI}) 10 \mathrm{mg} / \mathrm{L})$

Menurut Venugopal et al, (2011) semakin lama waktu kontak semakin banyak logam yang terserap karena semakin banyak kesempatan partikel adsorben untuk bersinggungan dengan logam. Tetapi apabila adsorbennya telah jenuh, maka waktu kontak tidak lagi berpengaruh terhadap daya serap. Pada waktu kontak 180 menit terjadi penurunan kapasitas serapan. Hal ini terjadi karena waktu kontak yang terlalu lama menyebabkan terjadinya peristiwa desorpsi adsorbat dari permukaan adsorben disebabkan karena permukaan adsorben telah jenuh. Sesuai dengan Wiraman (2011), pada awal reaksi, peristiwa adsorpsi lebih dominan dibandingkan dengan peristiwa desorpsi, sehingga adsorpsi berlangsung cepat. Pada waktu tertentu peristiwa adsorpsi cenderung berlangsung lambat dan sebaliknya laju desorpsi cenderung meningkat

\section{Penentuan Konsentrasi Optimum}

Pengaruh konsentrasi terhadap jumlah ion $\mathrm{Cr}(\mathrm{VI})$ yang teradsorpsi oleh adsorben dipelajari dengan memvariasikan konsentrasi larutan $\mathrm{Cr}(\mathrm{VI})$ yaitu 10; 20; 30; $40 ; 50,60,70,80$, dan $90 \mathrm{mg} / \mathrm{L}$ pada waktu kontak optimum yaitu 120 menit. Hasil kajian adsorpsi disajikan pada Gambar 5. Adsorpsi ion $\mathrm{Cr}(\mathrm{VI})$ oleh adsorben menunjukan peningkatan jumlah ion $\mathrm{Cr}(\mathrm{VI})$ yang teradsorpsi jika konsentrasi ion $\mathrm{Cr}(\mathrm{VI})$ dinaikkan dan mencapai optimum pada konsentrasi $70 \mathrm{mg} / \mathrm{L}$. Hal ini terjadi karena situs aktif yang terdapat pada permukaan adsorben belum jenuh dengan zat teradsorpsi. Selanjutnya jika situs aktif pada permukaan adsorben telah jenuh oleh zat teradsorpsi peningkatan konsentrasi ion $\mathrm{Cr}(\mathrm{VI})$ tidak lagi meningkatkan adsorpsi ion Cr(VI). Wiraman (2011) mengatakan bahwa jika situs aktif yang terdapat pada permukaan adsorben belum jenuh oleh zat adsorbat, maka dengan memperbesar konsentrasi adsorbat, jumlah adsorbat yang teradsorpsi akan meningkat secara linear.



Gambar 5. Grafik pengaruh konsentrasi ion $\mathrm{Cr}(\mathrm{VI})$ terhadap serapan adsorben

Pada konsentrasi rendah yaitu 10 $\mathrm{mg} / \mathrm{L}$ efisiensi penyerapan adsorben lumpur diaktivasi mencapai 80,78\% dengan serapan sebesar $0,383 \mathrm{mg} / \mathrm{g}$ dan mencapai kondisi optimum pada konsentrasi $70 \mathrm{mg} / \mathrm{L}$ dengan serapan sebesar $1,919 \mathrm{mg} / \mathrm{g}$ dan efisiensi penyerapan 53,89 \%. Sedangkan untuk adsorben lumpur segar pada konsentrasi rendah yaitu $10 \mathrm{mg} / \mathrm{L}$ serapan terhadap $\mathrm{Cr}(\mathrm{VI})$ sebesar $0,471 \mathrm{mg} / \mathrm{g}$ dan efisiensi penyerapan mencapai 99,25\%. Serapan optimum terjadi pada konsentrasi $70 \mathrm{mg} / \mathrm{L}$ dengan serapan sebesar 2,057 $\mathrm{mg} / \mathrm{g}$ dan efisiensi penyerapan hanya $57,77 \%$. Hal ini sesuai dengan Venugopal et al., (2011) yang mengatakan bahwa dengan meningkatnya konsentrasi ion logam efisiensi penyerapan semakin berkurang, dikarenakan kemampuan menyerap adsorben terhadap ion logam sudah maksimum dimana penurunan efisiensi penyerapan pada konsentrasi tinggi terjadi karena jumlah ion logam dalam larutan 
tidak sebanding dengan jumlah partikel adsorben yang tersedia sehingga adsorben akan mencapai titik jenuh dan efisiensi penyerapan akan berkurang.

Kemampuan serapan pada lumpur segar terjadi karena adanya kandungan silika dan alumina sebanyak 49,02 \% dan $16,49 \%$ yang berperan sebagai sisi aktif adsorben. Saat dilakukan pemanasan pada suhu $600^{\circ} \mathrm{C}$ pada adsorben lumpur diaktivasi, terjadi penguraian senyawa organik yang ditunjukan dengan kehilangan massa yang disebabkan karena pengaruh campuran didalam bahan yang bersifat volatil. Sedangkan pada silika dan alumina yang terkandung didalam bahan tidak ikut menguap karena titik lebur dari silika dan alumina berada diatas suhu $600^{\circ} \mathrm{C}$. yaitu $1414^{\circ} \mathrm{C}$ untuk silika dan $660,32^{\circ} \mathrm{C}$ untuk alumina (Wikipedia, 2015). Rusmawati (2007) menjelaskan bahwa silika adalah salah satu bahan anorganik yang memiliki kelebihan sifat stabil terhadap pengaruh mekanik, temperatur dan kondisi keasaman. Selanjutnya Rusmawati (2007) mengatakan bahwa proses pemanasan bertujuan untuk mengaktifkan ikatan $\mathrm{Si}$ dengan $\mathrm{O}$ membentuk $\mathrm{SiO}_{2}$.

\section{Penentuan Kapasitas Serapan Maksimum Terhadap Ion $\mathrm{Cr}(\mathrm{VI})$}

Berdasarkan penelitian yang telah dilakukan tetapan kesetimbangan/afinitas serapan tertinggi yaitu pada adsorben lumpur segar sebesar 0,846 dan kapasitas adsorpsi maksimum sebesar 2,232 mg/g. Hal ini terjadi karena adanya silika dan alumina yang berperan pada sisi aktif adsorben. Sedangkan pada adsorben lumpur diaktivasi afinitas serapannya hanya 0,1529 dan kapasitas adsorpsi maksimum sebesar $2,075 \mathrm{mg} / \mathrm{g}$. Lebih rendahnya kapasitas adsorbsi adsorben lumpur diaktivasi diduga karena belum sempurnanya proses karbonasi saat aktivasi. Menurut Ncibi et al., (2014) dan Lozano-Castello' et al., (2001) proses Karbonasi, adalah rangkaian dari proses aktivasi adsorben. Selama proses karbonasi dialirkan gas nitrogen secara kontinyu dengan laju alir yang konstan dimana berguna untuk membersihkan dan menjamin sampel terbebas dari oksigen selama proses karbonasi. Sedangkan dalam penelitian ini proses karbonasi dilakukan dalam furnace tanpa mengalirkan gas nitrogen karena keterbatasan peralatan.

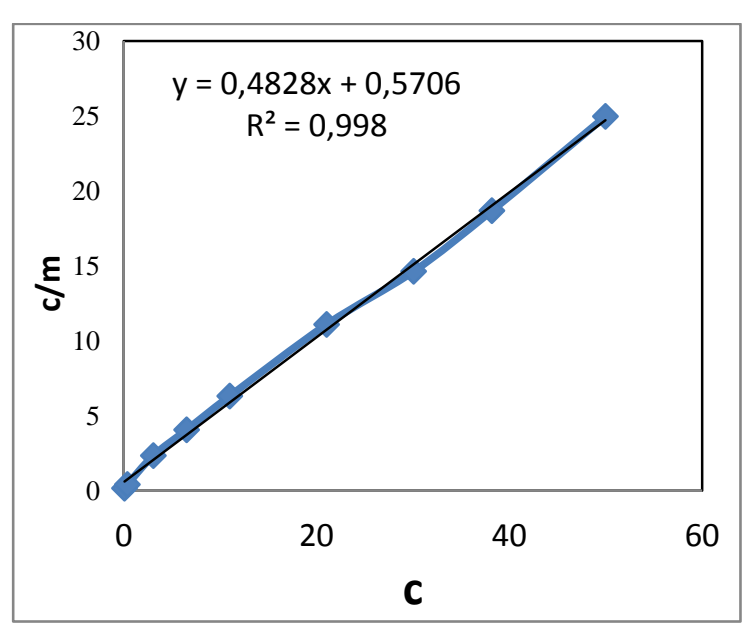

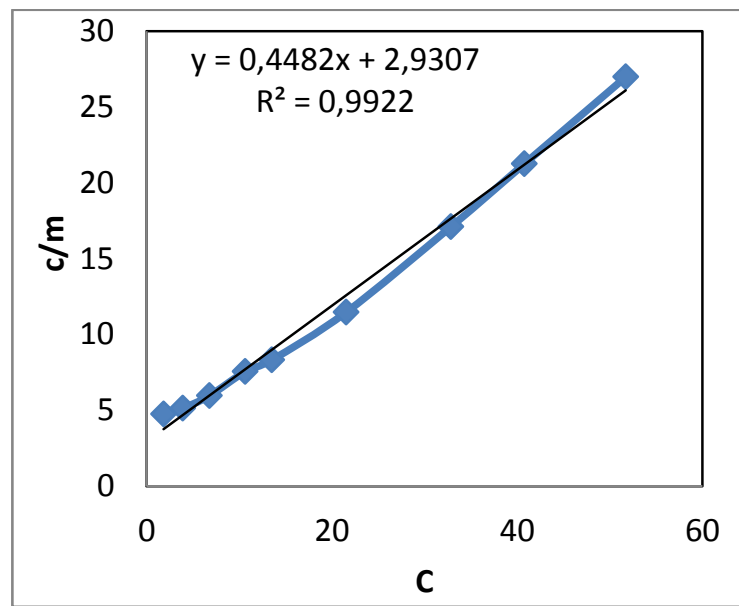

Gambar 6 dan 7. Grafik Isoterm Adsorpsi Langmuir Adsorben Lumpur Diaktivasi dan Adsorben Lumpur Segar

Data kapasitas adsobsi maksimum sesuai dengan isoterm Langmuir. Garfik isoterm adsorpsi langmuir adsorben lumpur diaktivasi dan adsorben lumpur segar dapat dilihat pada Gambar 6 dan Gambar 7. Wiraman (2011) menjelaskan bahwa Adsorpsi isoterm Langmuir merupakan model adsorpsi yang sangat sering digunakan untuk menunjukkan hubungan antara aktivitas adsorben dengan jumlah zat yang teradsorpsi pada temperatur konstan. Langmuir menjabarkan teori adsorpsinya bahwa pada permukaan adsorben terdapat sejumlah situs aktif 
tertentu yang proporsional dengan luas permukaan. Pada situs aktif tersebut hanya dapat mengadsorpsi satu molekul. Ikatan antara adsorben dan zat yang teradsorpsi dapat terjadi secara fisik atau kimia. Ikatan tersebut harus cukup kuat untuk menjaga terjadinya perpindahan molekul yang telah teradsorpsi sepanjang permukaan adsorben.

Adsorpsi ion $\mathrm{Cr}(\mathrm{VI})$ oleh Adsorben lumpur diaktivasi dan adsorben lumpur segar memenuhi persamaan isotherm adsorpsi Langmuir dengan koefisien korelasi $\left(R^{2}\right)$ masing-masing yaitu 0,992 dan 0,998 .

\section{KESIMPULAN}

Komposisi kimia dari limbah lumpur industri crumb rubber PT. Kilang Lima Gunung Lubuk Begalung Padang yaitu silika, alumina, dan beberapa oksida logam lain sehingga berpotensi dijadikan sebagai adsorben. Kondisi serapan maksimum adsorben lumpur diaktivasi dengan $\mathrm{KOH}$ terhadap ion $\mathrm{Cr}(\mathrm{VI})$ terjadi pada $\mathrm{pH} 1$ dan adsorben lumpur segar terjadi pada $\mathrm{pH} 2$ dengan waktu kontak optimum 120 menit dan konsentrasi larutan optimum masingmasing adsorben $70 \mathrm{mg} / \mathrm{L}$. Data hasil penelitian sesuai dengan isotherm Langmuir dengan kapasitas serapan maksimumnya adsorpsi adalah 0.846 dan $2.232 \mathrm{mg} / \mathrm{g}$ untuk adsorben lumpur segar dan 0.1529 dan $2.075 \mathrm{mg} / \mathrm{g}$ untuk lumpur diaktivasi dengan $\mathrm{KOH}$. Lebih rendahnya kapasitas adsorbsi adsorben lumpur diaktivasi diduga karena belum sempurnanya proses karbonasi saat aktivasi

\section{Saran}

Penelitian lanjutan sebaiknya dilakukan guna menyempurnakan proses aktivasi.

\section{DAFTAR PUSTAKA}

Benaïssa, H., \& Elouchdi, M. A. 2011. Biosorption of copper (II) ions from synthetic aqueous solutions by drying bed activated sludge. Journal of Hazardous Materials, 194, 69-78.
Bhattacharya, A., Naiya, T., Mandal, S., \& Das, S. 2008. Adsorption, kinetics and equilibrium studies on removal of $\mathrm{Cr}(\mathrm{VI})$ from aqueous solutions using different low-cost adsorbents. Chemical Engineering Journal. 137. 529-541

Chen, S., Yue, Q., Gao, B., Li, Q., \& Xu, X. 2011. Removal of $\mathrm{Cr}(\mathrm{VI})$ from aqueous solution using modified corn stalks: Characteristic, equilibrium, kinetic and thermodynamic study. Chemical Engineering Journal, 168(2), 909-917.

Demirbas, E., Kobya, M., Senturk, E., Ozkan, T. 2004. Adsorption kinetics for the removal of chromium (VI) from aqueous solutions on the activated carbons prepared from agricultural wastes. Water SA 30, 533-539.

Gorzin, F., \& Ghoreyshi, A. A. 2013. Synthesis of a new low-cost activated carbon from activated sludge for the removal of $\mathrm{Cr}(\mathrm{VI})$ from aqueous solution: Equilibrium, kinetics, thermodynamics and desorption studies. Korean Journal of Chemical Engineering, 30(8), 1594-1602.

Gupta, S., \& Babu, B. V. 2009a. Utilization of waste product (tamarind seeds) for the removal of $\mathrm{Cr}(\mathrm{VI})$ from aqueous solutions: Equilibrium, kinetics, and regeneration studies. Journal of Environmental Management, 90(10), 3013-3022.

Gupta, S., \& Babu, B. V. 2009b. Removal of toxic metal $\mathrm{Cr}(\mathrm{VI})$ from aqueous solutions using sawdust as adsorbent: Equilibrium, kinetics and regeneration studies. Chemical Engineering Journal, 150(2-3), 352-365.

Hunsom, M., \& Autthanit, C. 2013. Adsorptive purification of crude glycerol by sewage sludge-derived activated carbon prepared by chemical activation with $\mathrm{H} 3 \mathrm{PO} 4, \mathrm{~K} 2 \mathrm{CO} 3$ and $\mathrm{KOH}$. Chemical Engineering Journal, 229, 334-343.

Hwang, H. R., Choi, W. J., Kim, T. J., Kim, J. S., \& Oh, K. J. 2008. The preparation of an adsorbent from mixtures of sewage sludge and coal-tar 
pitch using an alkaline hydroxide activation agent. Journal of Analytical and Applied Pyrolysis, 83(2), 220-226.

Iddou, A., \& Ouali, M. S. 2008. Wasteactivated sludge (WAS) as $\mathrm{Cr}$ (III) sorbent biosolid from wastewater effluent. Colloids and Surfaces $B$ : Biointerfaces, 66(2), 240-245.

Jain, M., Garg, V. K., \& Kadirvelu, K. 2010. Adsorption of hexavalent chromium from aqueous medium onto carbonaceous adsorbents prepared from waste biomass. Journal of Environmental Management, 91(4), 949-957.

Javadian, H., Ahmadi, M., Ghiasvand, M., Kahrizi, S., \& Katal, R. 2013. Removal of $\mathrm{Cr}(\mathrm{VI})$ by modified brown algae Sargassum bevanom from aqueous solution and industrial wastewater. Journal of the Taiwan Institute of Chemical Engineers, 44(6), 977-989.

Liu, C. C., Li, Y. S., Chen, Y. M., Wang, M. K., Chiou, C. S., Yang, C. Y., \& Lin, Y. A. 2011. Biosorption of chromium, copper and zinc on rice wine processing waste sludge in fixed bed. Desalination, 267(1), 20-24.

Lozano-Castelló, D., Lillo-Ródenas, M. A., Cazorla-Amorós, D., \& Linares-Solano, A. 2001. Preparation of activated carbons from Spanish anthracite-I. Activation by $\mathrm{KOH}$. Carbon, 39(5), 741-749.

Ncibi, M. C., Ranguin, R., Pintor, M. J., Jeanne-rose, V., Sillanpää, M., \& Gaspard, S. 2014. Pyrolysis Preparation and characterization of chemically activated carbons derived from Mediterranean Posidonia oceanica (L.) fibres. Journal of Analytical and Applied Pyrolysis, 109, 205-214.

Monsalvo, V. M., Mohedano, A. F, Rodriguez, J. J. 2012. Adsorption of 4chlorophenol by inexpensive sewage sludge-based adsorbents. Chemical Engineering Research and Design 90 1807-1814

Pillai, S. S., Mullassery, M. D., Fernandez, N. B., Girija, N., Geetha, P., \& Koshy,
M. 2013. Biosorption of $\mathrm{Cr}(\mathrm{VI})$ from aqueous solution by chemically modified potato starch: Equilibrium and kinetic studies. Ecotoxicology and Environmental Safety, 92, 199-205.

Siswoyo, E., Mihara, Y., \& Tanaka, S. 2014. Determination of key components and adsorption capacity of a low cost adsorbent based on sludge of drinking water treatment plant to adsorb cadmium ion in water. Applied Clay Science, 97-98, 146-152.

Ranganathan, K., 2000. Chromium removal by activated carbons prepared from Casurina equisetifolia leaves. Bioresource Technology 73, 99-103.

Rusmawati,. 2007. Studi Pengaruh Temperatur Sintering Sekam Padi sebagai Bahan Pembuatan Membran Silika Berpori. Tugas Akhir S1 Jurusan Fisika FMIPA UNDIP.

Salmariza.Sy. 2012. Pemanfaatan Limbah Lumpur Proses Activated Sludge Industri Karet Remah Sebagai Adsorben. Jurnal Riset Industri, Volume VI (2). 59-66

Salmariza.Sy, Mawardi, Resti Hariyani dan Monik Kasman 2014. Pengembangan Adsorben Dari Limbah Lumpur Industri Crumb Rubber Yang Diaktivasi Dengan $\mathrm{H}_{3} \mathrm{PO}_{4}$ Untuk Menyerap Ion $\mathrm{Cr}(\mathrm{VI})$. Jurnal Litbang Industri Vol 4 (2). 67-77

Smith, K.M., Fowler, G.D., Pullket, S., Graham, N.J.D., 2009. Sewage sludge-based adsorbents: a review of their production, properties and use in water treatment applications. Water Res. 43 (10), 2569-2594.

Svehla. 1985. Vogel: Buku Teks Analisis Anorganik Kualitatif Makro dan Semimikro. (Terjemahan oleh Setiono L.,Pudjaatmaka A.H), Edisi Kelima. Jakarta: PT. Kalman MediaPustaka.

Venugopal, V., \& Mohanty, K. 2011. Biosorptive uptake of $\mathrm{Cr}(\mathrm{VI})$ from aqueous solutions by Parthenium hysterophorus weed: Equilibrium, kinetics and thermodynamic studies. Chemical Engineering Journal, 174(1), 151-158. 
Wang, X. S., Tang, Y. P., \& Tao, S. R. 2009. Kinetics, equilibrium and thermodynamic study on removal of $\mathrm{Cr}(\mathrm{VI})$ from aqueous solutions using low-cost adsorbent Alligator weed. Chemical Engineering Journal, 148(23), 217-225.

Wikipedia.org/wiki/Silika dan Alumina, diakses tanggal 24 Juli 2015.

Wiraman, T. 2011. Adsorpsi Krom (VI) Oleh Arang aktif Termodifikasi dari Tempurung Jarak Pagar (Jatropha Curcas. L). Jurnal Mulawarman Scientifie, vol. 10, No 1.

Wu, J., Zhang, H., He, P. J., Yao, Q., \& Shao, L. M. 2010. Cr(VI) removal from aqueous solution by dried activated sludge biomass. Journal of Hazardous Materials, 176(1-3), 697-703.
Yang, C., Wang, J., Lei, M., Xie, G., Zeng, G., \& Luo, S. 2010. Biosorption of zinc(II) from aqueous solution by dried activated sludge. Journal of Environmental Sciences, 22(5), 675680.

Zaini, M. A. A., Zakaria, M., Mohd.-Setapar, S. H., \& Che-Yunus, M. A. 2013. Sludge-adsorbents from palm oil mill effluent for methylene blue removal. Journal of Environmental Chemical Engineering, 1(4), 1091-1098. 